Published by Al-Nahrain College of Medicine P-ISSN 1681-6579 E-ISSN 2224-4719

Email: iraqijms@colmed-alnahrain.edu.iq http://www.colmed-alnahrain.edu.iq http://www.iraqijms.net Iraqi JMS 2018; Vol. 16(4)

\title{
Detection of Some Biofilm Genes Related with Multidrug- Resistant in Acinobacter baumannii Isolated from Clinical Isolates
}

\author{
Sura S. Talib MSc, Thanaa R. Abdulrahman ${ }^{1} P h D$, Shatha H. Ali ${ }^{2} P h D$ \\ ${ }^{1}$ Dept. of Microbiology, ${ }^{2}$ Dept. of Pediatrics, College of Medicine, Al-Nahrain University, Baghdad, Iraq
}

\begin{abstract}
Objective

Methods
\end{abstract}

Background Acinetobacter baumannii (A. baumanii) has recently emerged as a major pathogen causing nosocomial infections in patients admitted to intensive care units with a surprisingly rapid acquisition of antibiotic resistance.

To study the rate of occurrence of $A$. baumanii in different clinical samples and to investigate the association between biofilm formation and presence of ompA and bap genes in multi-drug resistance isolates. A total of 150 clinical samples were collected from (blood, sputum, urine, wound swab) during a period from the first of October 2017 to the end of March 2018 from Al-Imamein Al-Kadhimein City, Central Teaching Hospital of Pediatrics, Welfare Children Protection in Medical City and Al-Yarmouk Teaching Hospital and tested against 14 antibiotics by disc diffusion method. Quantitative microtiter plate assay was done for detection of biofilm formation. Polymerase chain reaction (PCR) was performed to detect ompA and bap genes.

Results There were 75 A. baumanii isolated from different clinical samples as follows: 41 from blood, 13 from wound, 12 from sputum and 9 from urine. The results of antimicrobial susceptibility test showed, high rate of resistance to Aztronem (94.7\%) followed by Cefotaxime (89.3\%), Cefepim (86.7\%), Meropinem (86.7\%), Ceftriaxone (86.7\%), Ceftazidime (85\%), Gentamicin (85\%), and Piperacillin $(82.7 \%)$ respectively. Moderate - to - low rate of resistance to Ciprofloxacin (78\%), Impenim (46.7\%), Levofloxacin (46\%), Amikacin (44\%), Tigacycline $(42.3 \%)$ and Colistin (44\%). The detection of biofilm formation showed that $(52 \%)$ of isolate produce biofilm and the prevalence of ompA gene was $86.7 \%$ while the prevalence of Bap-gene was $34.7 \%$.

Conclusion High frequency of $A$. baumannii infection was observed in different hospitals in Baghdad. More than half of the isolates were biofilm producer and there is highly significant association between the presence of bap gene and the biofilm formation but not with ompA gene.

Keywords Citation Acinetobacter baumannii, ompA, Bap, MD

Talib SS, Abdulrahman TR, Ali SH. Detection of some biofilm genes related with multidrugresistant in Acinobacter baumannii isolated from clinical isolates. Iraqi JMS. 2018; 16(4): 430438. doi: 10.22578/IJMS.16.4.11

List of abbreviations: Bap = Biofilm associated protein, $\mathrm{bp}=$ Base pair/ base pairs, CFU = Colony forming unit, CLSI = Clinical \& Laboratory Standards Institute, DNA = Deoxy Ribo Nucleic Acid, MDR = Multi drug resistant, $\mathrm{OMPA}=$ Outer membrane protein $\mathrm{A}, \mathrm{PCR}=$ Polymerase chain reaction

\section{Introduction}

$A$ cinetobacter baumannii (A. baumanii) is a Gram-negative bacterium related to hospital-acquired infection, especially in intensive care unit (ICU) where it causes bacteremia, pneumonia, meningitis, urinary tract infection and wound infection ${ }^{(1)}$. Serious infections caused by $A$. baumanii are usually cured by imipenem as an efficient drug of choice. However, reports of imipenemresistant $A$. baumannii strains have been increasing significantly over recent years and these isolates are often multidrug-resistant (MDR) ${ }^{(2)}$. One of the major factor involved in bacterial resistance to antimicrobial, chronic infections or survival in varying environments is 
the ability to form biofilms. Biofilms are complex mixtures of microbes which are predominantly attached to hard surfaces. They are often enclosed by thick polysaccharide layer which makes them resistant to antibiotics and thus very hard to eliminate (3). On the other hand, sensitivity to different antibiotics as well as microbial metabolism due to biofilm formation will be reduced. This is attributable to lack of food in the biofilm depth. Slower metabolism and antibiotic resistance lead to bacterial dissemination which can create a quick critical situation ${ }^{(4)}$. There is a variety of virulence determinants involved in biofilm formation of $A$. baumannii. This bacterium produces a molecule called the biofilmassociated protein (Bap), which is encoded by the bap gene ${ }^{(5)}$.

BAP contributes to the initiation of biofilm production after $A$. baumannii attaches to a particular surface ${ }^{(6)}$. Bap is a member of a group of surface proteins, which have high molecular mass with tandem repeats of domains involved in intercellular adhesion. Bap is a large protein $(854 \mathrm{kDa}$ ) characterized in a bloodstream isolate of $A$. baumannii and Loehfelm et al., 2008 (7) suggested the development and thickness of the mature biofilm structure was associated with this protein.

OmpA is a porin and one of the major protein in the outer membrane with a molecular mass of $38 \mathrm{kDa}$. Data have shown that this protein plays a role in biofilm formation on plastic, and also in the interaction of human epithelial cells and Candida albicans filaments ${ }^{(8)}$.

The objectives of this study was to study the rate of occurrence of $A$. baumanii in different clinical samples and to investigate the association between biofilm formation and presence of OMPA and BAP genes in MDR isolates.

\section{Methods}

A total of 150 patients were enrolled in this study. Different clinical samples (blood, sputum, urine, wound swab) were collected during a period from the first of October 2017 to the end of March 2018 from Al-Imamein AlKadhimein Medical City, Central Teaching Hospital of Pediatric, Welfare Children Protection in Medical City and Al-Yarmouk Teaching Hospital/Baghdad. Bacteria were isolated and identified by ordinary methods according to morphological characteristics on cultures and by biochemical tests in the laboratories of Microbiology Department, College of Medicine, Al-Nahrain University. A loopful of pure colony was used to confirm identification by the phenotypic VITEK-2 Systems method.

\section{Antibiotic susceptibility testing}

Seventy-five of $A$. baumannii isolates were tested for their susceptibility to fourteen antimicrobial agents include Aztronem, Cefotaxime, Ceftriaxone, Ceftazidime, Ciprofloxacin, Levofloxacin, Tigacycline, Peperacillin, Colistin, Gentamicin, Amikacin, Cefepim, Imipenem and Meropinem in accordance to Clinical \& Laboratory Standards Institute (2016) recommendations.

\section{Detection of biofilm formation.}

Quantitative microtiter plate assays for biofilm formation were performed according to Brossard and Campagnari (2012) (9) as follows: A $100 \mu \mathrm{l}$ of $A$. baumannii broth turbidity equal to $0.5 \mathrm{McF}$ arland and an equal volume of Luria Bertain (LB) broth supplemented with $20 \%$ glucose were added to each well in 96-well polystyrene microtiter plates. The plates were incubated overnight at $37^{\circ} \mathrm{C}$. The cultures were softly removed. The wells were washed three times with phosphate buffered saline. The adherent cells were fixed with absolute methanol for $10 \mathrm{~min}$, stained with $0.4 \%$ crystal violet for $15 \mathrm{~min}$, washed three times with sterile distilled water and then allowed for airdried. The plates were filled with $250 \mu$ l of $33 \%$ acetic acid and waited for $15 \mathrm{~min}$. The reading of OD at $595 \mathrm{~nm}$ absorbance was determined. Chromosomal DNA of $A$. baumannii isolates was extracted using genomic DNA extraction 
kit (Promega, USA). The extracted DNA used as a template in Polymerase chain reaction (PCR). Specific primer sequences of OmpA, and Bap were amplified by PCR, table (1). Twenty-five microlitter of PCR mixture reaction were prepared according to the program published by Badmasti et al. in $2015^{(10)}$.

Table 1. Sequences and products of ompA and Bap genes

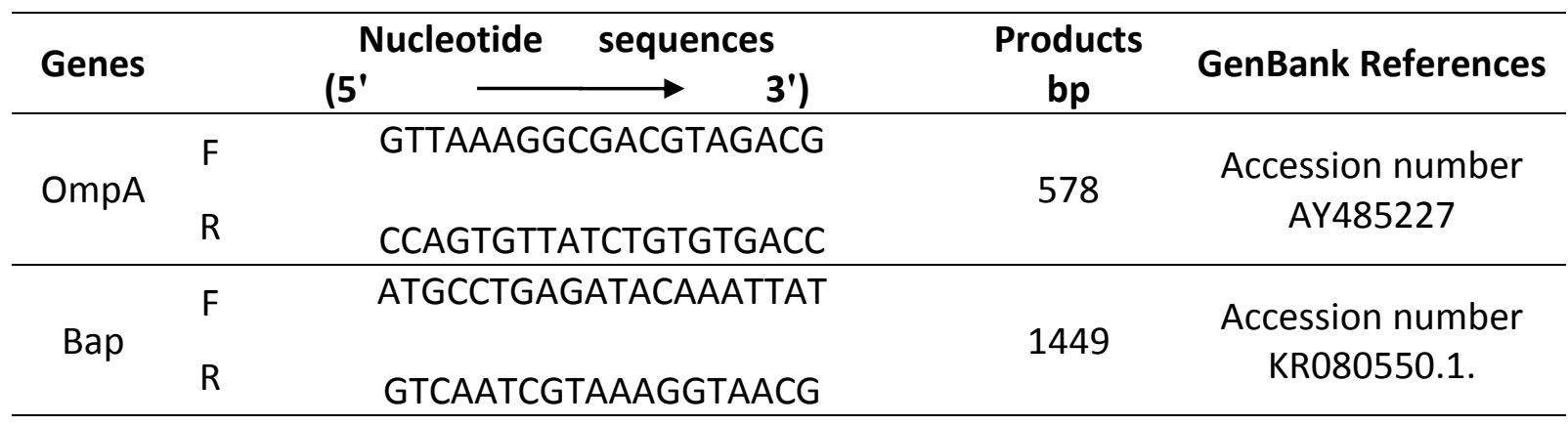

The primers diluted by adding nuclease free water depending on the manufacture companies' instructions

The master mix contents were thawed before use at room temperature, and the PCR master mix was prepared on a separate biohazard safety cabinet with wearing hand gloves at all times to avoid contamination.

$2.0 \mu \mathrm{l}$ of each forward and revers specific primers was mixed with $12.5 \mu \mathrm{l}$ PCR master mix tubes, $3 \mu$ of DNA template was added then the volumes were completed to $25 \mu \mathrm{l}$ by nuclease free water.

A $25 \mu \mathrm{l}$ of the PCR mixture were spun down with a mini centrifuge.

The tubes were placed on the PCR machine and the PCR program with the cycling conditions was installed according to, the Cleaver Scientific Thermal Cyclers TC32/80 was used for all PCR amplification reactions.

Initial denaturation step at $95{ }^{\circ} \mathrm{C}$ for 60 seconds, denaturation step $94{ }^{\circ} \mathrm{C}$, annealing step $50{ }^{\circ} \mathrm{C}$, extension $72{ }^{\circ} \mathrm{C}$ for 60 seconds and final extension $72{ }^{\circ} \mathrm{C}$ for 3 minutes, total of cycles 22 cycle.

A $7 \mu \mathrm{L}$ of each amplified sequence and $100 \mathrm{bp}$ ladder resolved by electrophoresis according to Sambrook and Russell (2001) ${ }^{(11)}$. The products were visualized in UV Tran- illuminator (LKB, Sweden).

\section{Results}

There were $75 A$. baumanii isolates from different clinical samples as follows: 41 from blood, 13 from wound, 12 from sputum and 9 from urine. This study includes 44 males and 31 females. The percentage was $58.7 \%$ and $41.3 \%$ of males and females respectively.

\section{Antibiotics by disc-diffusion method}

The results of antimicrobial susceptibility test are showed in table (2).

Detection of biofilm formation in $A$. baumannii isolates and its association with antibiotic resistance

The current study showed that (52\%) of $A$. baumannii isolates were produced biofilm while (48.0\%) not biofilm producer.

All biofilm producer isolates were resistant to four or more antibiotics of different classes, which considered as Multidrug resistance (MDR). This study showed that, out of 39 biofilm producer there were 12 isolates sensitive to tigacyclin and 10 isolates sensitive to colistin, in addition to one isolate was sensitive to peperacillin. Statistically there is significant association between biofilm and antibiotic resistance (Table 3 ). 
Table 2. Susceptibility of $A$. baumannii to different antibiotics using disc-diffusion method

\begin{tabular}{cccc}
\hline Antibiotic disc & Sensitive & Resistance & Intermediate \\
\hline Amikacin & $25(33.3 \%)$ & $33(44.0 \%)$ & $17(22.7 \%)$ \\
Aztronem & $4(5.3 \%)$ & $71(94.7 \%)$ & $0(0.0 \%)$ \\
Ceftriaxone & $10(13.3 \%)$ & $65(86.7 \%)$ & $0(0.0 \%)$ \\
Ceftazidime & $11(14.7 \%)$ & $64(85.0 \%)$ & $0(0.0 \%)$ \\
Cefepim & $10(13.3 \%)$ & $65(86.7 \%)$ & $0(0.0 \%)$ \\
Cefotaxime & $8(10.7 \%)$ & $67(89.3 \%)$ & $0(0.0 \%)$ \\
Colistin & $36(48.0 \%)$ & $31(41.0 \%)$ & $8(10.7 \%)$ \\
Ciprofloxacin & $12(16.0 \%)$ & $59(78.0 \%)$ & $4(5.3 \%)$ \\
Levofloxacin & $31(41.0 \%)$ & $35(46.0 \%)$ & $9(12.0 \%)$ \\
Impenim & $32(42.7 \%)$ & $35(46.7 \%)$ & $8(10.7 \%)$ \\
Meropinem & $9(12.0 \%)$ & $65(86.7 \%)$ & $1(1.3 \%)$ \\
Tigacycline & $35(46.7 \%)$ & $31(41.3 \%)$ & $9(12.0 \%)$ \\
Gentamicin & $6(8.0 \%)$ & $64(85.0 \%)$ & $5(6.7 \%)$ \\
Piperacillin & $13(17.3 \%)$ & $62(82.7 \%)$ & -
\end{tabular}

\section{Gene amplification}

By PCR essay, the amplification of ompA and Bap genes in chromosomal DNA of $A$. bamannii was produced an amplicon of size $578 \mathrm{bp}$ and $1449 \mathrm{bp}$ respectively (Figures 1 and 2). The present results also showed that, the prevalence of ompA gene was $86.7 \%$ in DNA of isolates, while the prevalence of Bap-gene was $34.7 \%$.

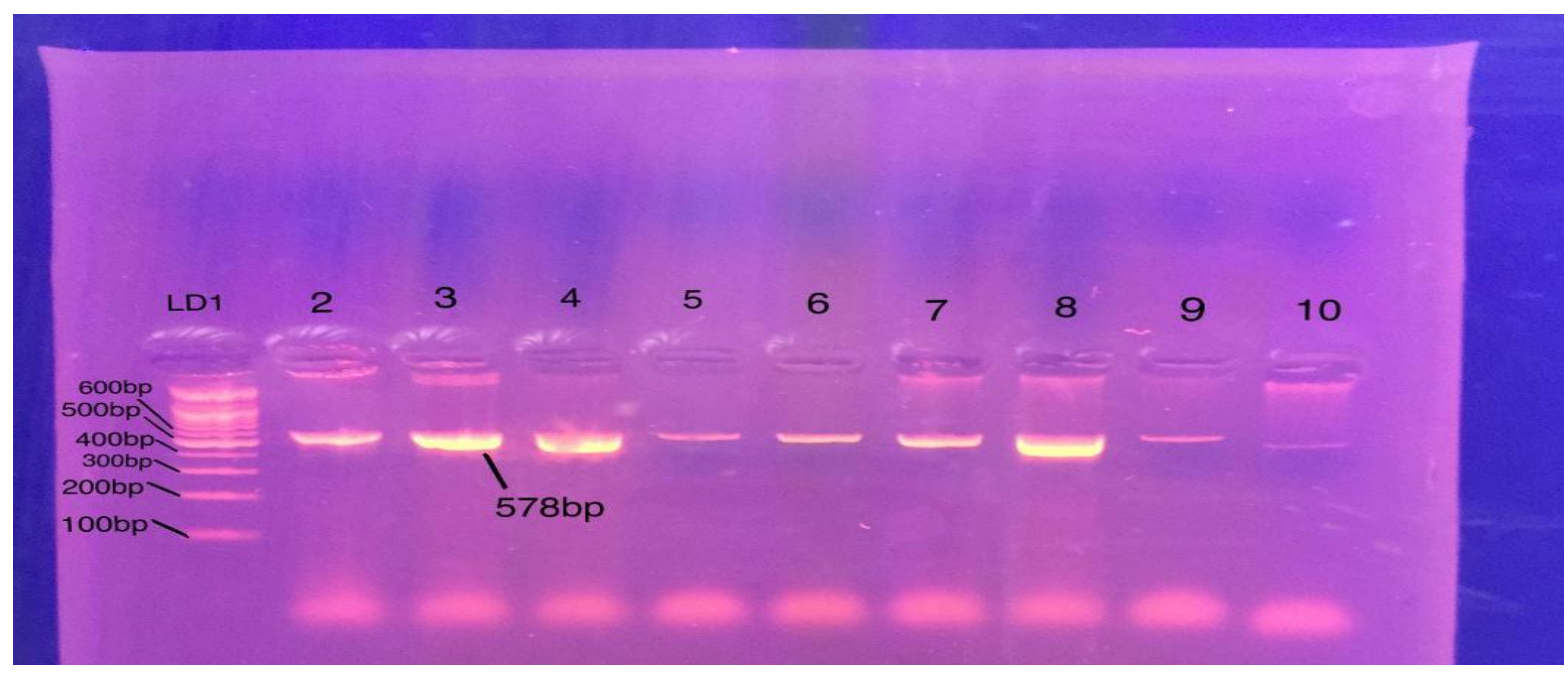

Figure 1. Gel electrophoresis of amplified ompA gene(578bp). Lane 1: $100 \mathrm{bp}$ ladder. Lanes 2-10: Clinical isolates showing positive result (1.5\% agarose, $\left.7 \mathrm{v} / \mathrm{cm}^{2}, 1.5 \mathrm{hrs}\right)$ 
Talib et al, Biofilm genes in multidrug-resistant in Acinobacter baumannii

Table 3. The association between biofilm and antibiotic resistance

\begin{tabular}{|c|c|c|c|c|}
\hline \multirow{2}{*}{ Antibiotic } & & \multicolumn{2}{|c|}{ Biofilm } & \multirow{2}{*}{$P$ value } \\
\hline & & Negative & Positive & \\
\hline \multirow{3}{*}{ AK } & 1 & 8 & 0 & \multirow{3}{*}{0.000} \\
\hline & $\mathrm{R}$ & 9 & 39 & \\
\hline & $S$ & 19 & 0 & \\
\hline \multirow{2}{*}{$\mathrm{AZT}$} & $\mathrm{R}$ & 32 & 39 & \multirow{2}{*}{0.004} \\
\hline & $S$ & 4 & 0 & \\
\hline \multirow{2}{*}{ CRO } & $\mathrm{R}$ & 27 & 39 & \multirow{2}{*}{0.001} \\
\hline & $S$ & 9 & 0 & \\
\hline \multirow{2}{*}{ CAZ } & $\mathrm{R}$ & 26 & 39 & \multirow{2}{*}{0.000} \\
\hline & $S$ & 10 & 0 & \\
\hline \multirow{2}{*}{ FEP } & $\mathrm{R}$ & 27 & 39 & \multirow{2}{*}{0.001} \\
\hline & $S$ & 9 & 0 & \\
\hline \multirow{3}{*}{ CTX } & $\mathrm{R}$ & 28 & 39 & \multirow{2}{*}{0.002} \\
\hline & $S$ & 8 & 0 & \\
\hline & 1 & 5 & 0 & \multirow{4}{*}{0.000} \\
\hline \multirow[t]{3}{*}{$\mathrm{CO}$} & $\mathrm{R}$ & 11 & 29 & \\
\hline & $S$ & 20 & 10 & \\
\hline & 1 & 2 & 0 & \\
\hline \multirow[t]{3}{*}{ CIP } & $\mathrm{R}$ & 28 & 39 & \multirow[t]{3}{*}{0.002} \\
\hline & $S$ & 6 & 0 & \\
\hline & 1 & 3 & 0 & \\
\hline \multirow[t]{3}{*}{ LEVO } & $\mathrm{R}$ & 13 & 39 & \multirow[t]{3}{*}{0.000} \\
\hline & $\mathrm{S}$ & 20 & 0 & \\
\hline & 1 & 5 & 0 & \\
\hline \multirow[t]{2}{*}{ IMP } & $\mathrm{R}$ & 11 & 39 & \multirow[t]{2}{*}{0.000} \\
\hline & $S$ & 20 & 0 & \\
\hline \multirow{3}{*}{ MEM } & $\mathrm{R}$ & 32 & 39 & \multirow{3}{*}{0.004} \\
\hline & $S$ & 4 & 0 & \\
\hline & 1 & 3 & 0 & \\
\hline \multirow[t]{3}{*}{ TG } & $\mathrm{R}$ & 16 & 27 & \multirow[t]{3}{*}{0.005} \\
\hline & $S$ & 17 & 12 & \\
\hline & 1 & 4 & 0 & \\
\hline \multirow[t]{2}{*}{ GEN } & $\mathrm{R}$ & 28 & 39 & 0.003 \\
\hline & $S$ & 4 & 0 & \\
\hline PIP & $\mathrm{R}$ & 27 & 38 & 0005 \\
\hline rir & $\mathrm{S}$ & 9 & 1 & 0.005 \\
\hline
\end{tabular}




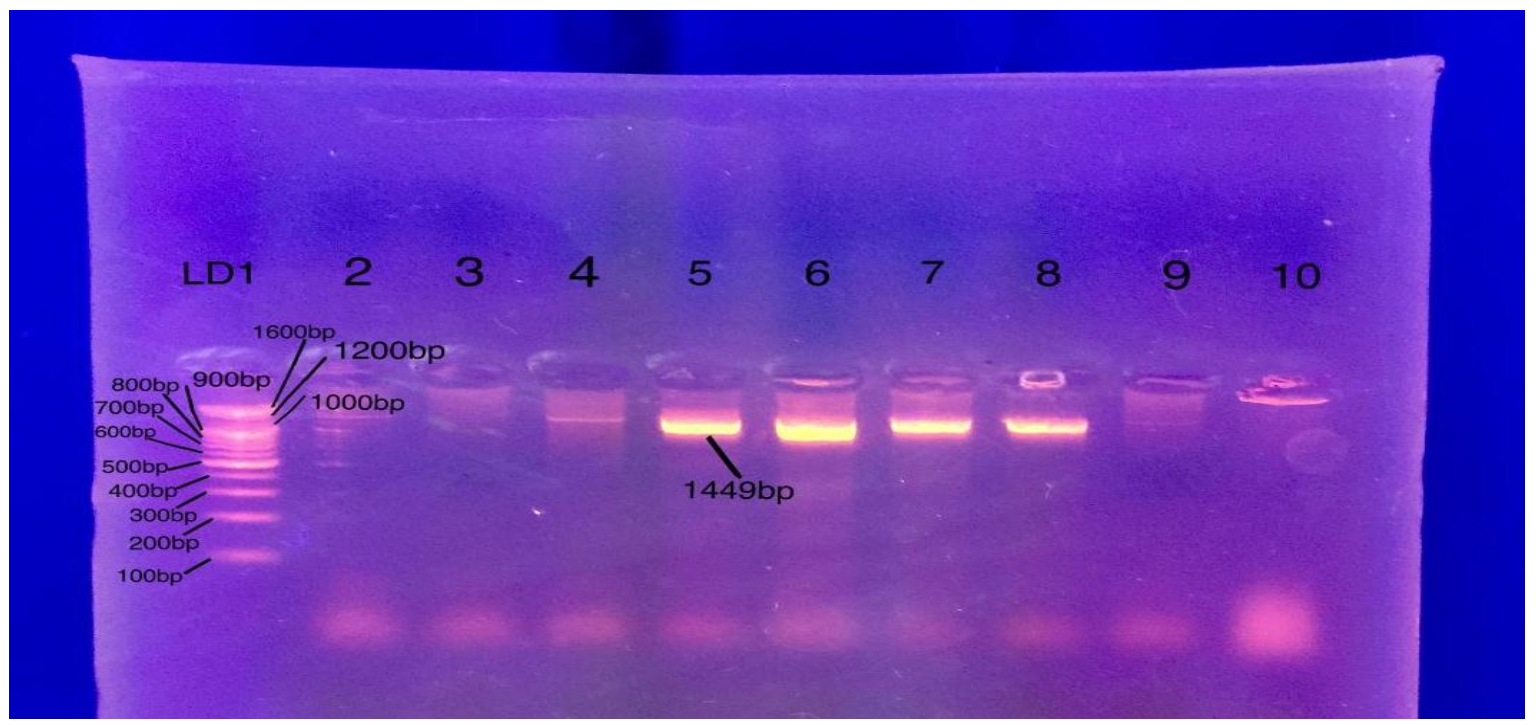

Figure 2. Gel electrophoresis of amplified Bap-gene (1449 bp) in genomic DNA using PCR with specific primers Lanes 4-8: Clinical isolates showing positive result. $\left(1.5 \%\right.$ agarose, $7 \mathrm{v} / \mathrm{cm}^{2}, 1.5$ hrs)

Association between biofilm formation and presence of ompA and bap genes

Out of 39 isolates that produce biofilm there were $92.3 \%$ possessed ompA gene while out of 36 isolates that non biofilm producer there were $80.6 \%$ of isolates possessed ompA. Statistically there is no significant association between biofilm and presence of ompA.
On the other hand, the present study found that out of 26 isolates that possessed Bap gene there is $64 \%$ of isolates were biofilm producer and only $2.8 \%$ non-biofilm producer, statistically there is significant association between the presence of Bab gene and biofilm formation as shown in table (4).

Table 4. Association between biofilm and presence of ompA and Bap genes

\begin{tabular}{ccccc}
\hline \multirow{2}{*}{ Biofilm } & \multicolumn{2}{c}{ omp A } & \multicolumn{2}{c}{ Bap } \\
& Negative & Positive & Negative & Positive \\
\hline Negative & $7(19.4 \%)$ & $29(80.6 \%)$ & $35(97.2 \%)$ & $1(2.8 \%)$ \\
Positive & $3(7.7 \%)$ & $36(92.3 \%)$ & $14(35.9 \%)$ & $25(64.0 \%)$ \\
\hline Total & $10(13.3 \%)$ & $65(86.7 \%)$ & $49(65.0 \%)$ & $26(34.7 .0 \%)$ \\
\hline P value & \multicolumn{2}{c}{$0.124 *$ Ns } & \multicolumn{2}{c}{$0.001 * \mathrm{~S}$} \\
\hline
\end{tabular}

*Ns: non-significant

* S: significant

\section{Discussion}

This study revealed wide distribution of 75 (52.0\%) A. baumannii among Iraqi patients than other microorganism with different illness. These results were agreed with the study conducted in Baghdad by Al-Kadhmi, 2018 (12) who reported that $A$. baumannii isolated more than other bacteria. The present study also exhibited that the percentage of isolates were $(58.7 \%)$ in males and $(29.03 \%)$ in females. This study agreed with study in Iran (13) reported that, (67\%) of $A$. baumannii was in males and $(32.6 \%)$ in female. Also study in Palestine ${ }^{(14)}$ was reported that $(62.5 \%)$ in male and $(37.5 \%)$ in female, while the current result disagreed with study done in Iraq (15) was 
reported that, $A$. baumannii in males (42\%) less than in females (58\%). The percentage of $A$. baumannii infection in males more than in females because males were more exposed to the wars than female.

The result of this study showed that $100 \%$ of isolates are MDR when tested by standard disk diffusion method. The most result of antibiotic sensitivity that are the bacterial lowest resistance to colistin (44\%) and tigecyclin (42.3\%). This result is in agreement with study in USA by Qureshi et al., $2015^{(16)}$ who reported that about $(50 \%)$ of isolates were resistant to colistin. While this result disagreed with the study done in Thailand (2012), who reported that $(97 \%)$ of the isolates were sensitive to colistin (17). A study in Saudi Arabia showed that (3.9\%) of isolated resistance to colistin by Almously et al., $2013^{\left({ }^{18}\right)}$. Because this treatment is of little use, so there is little resistance to it.

In this study a very high percentage resistance of $A$. baumannii to antibiotic, similar findings showed in Thailand by Thummeepak et al., $2016^{(19)}$ who found that A. baumannii clinical isolates developed (82.2\%) of resistance to ceftazidime, $(78.7 \%)$ to meropenem, $(54 \%)$ to amikacin and (84\%) to ciprofloxacin. Also, study by Ghajavand $2015{ }^{(13)}$ who reported that resistance percentage (53\%) to amikacin, (52\%) of isolates resistance to impenim, $(43 \%)$ to amikacin, (79\%) to piperacillin, (86\%) to ceftazidime and $(87 \%)$ to ciprofloxacin.

The existence of $\beta$-lactamases, which is the most predominate mechanism of $\beta$-lactam resistance. These enzymes, at least partly, hydrolyze carbapenems along with extra $\beta$ lactams (20). Recently a new prolonged spectrum AmpC enzyme was recognized in $A$. baumannii, which able to hydrolyze aztronam, cefipime and ceftazidime (21).

In this study among 75 clinical isolates (52\%) of studied $A$. baumannii showed biofilm formation ability. This finding agreed with study conducted by Azizi et al., $2016^{(22)}$ who found that $(63 \%)$ of clinical $A$. baumannii isolates were positive for biofilm formation. Another study in Iran 2014 reported that $(66.6 \%)$ of isolated produce biofilm (6). Also study by Rodríguez-Baño et al., (23) who reported that Fifty-six (63\%) of isolates formed biofilm.

The differences in biofilm formation among clinical isolates, in association with the epidemicity of strains and the severity of infections (24).

The current result showed that (86.7\%) percentage of $A$. baumannii isolates have ompA gene, this result agreed with study conducted in Thailand (19) they found that (84\%) of $A$. baumannii were harbored ompA gene, while other study in Iran reported that all isolates of $A$. baumannii (100\%) had ompA gene $^{(10,22)}$.

ompA has been exhibited to play a role in a numerous of interactions with the host during infection, involved adherence/invasion to epithelial cells, initiation of apoptosis in host cells and differentiation of host immune cells (25).

This present study showed that the highest percentage of ompA gene were in males $(55.4 \%)$ than in females $(44.6 \%)$ but there is not denoting any major connection between the sex of the patients infected with $A$. baumannii and their chances of harboring ompA gene, this because the gene found in the same species bacteria which infect both female and male.

According to the PCR result the highest percentage of positive isolates to ompA gene (53.8\%) was in blood, while the lowest percentage (12.3\%) was in urine.

This study noted that the presence of ompA gene had no significant association with the presence of biofilm in clinical isolates, this result agreed with other result ${ }^{(19)}$ reported that there were no significant differences between biofilm producer and non-biofilm producer in the presence of ompA gene.

The current result showed that (34.7\%) percentage of $A$. baumannii isolates have Bap gene. Which agreed with study conducted in Iran $2015^{(10)}$ who reported that (30\%) of $A$. baumannii isolates positive for Bap gene while Fallah et al., $2017^{(26)}$ who found that (92\%) of clinical isolates of $A$. baumannii positive to Bap gene.

This study was found that, significant association between presence of Bap gene and 
biofilm formation. The result of this study in agreement with the study (26) who reported that there was strong association between the presence of Bap gene and biofilm formation in A. baumannii isolates. While disagreed with the study (19) who reported that no significant association between presence of Bap gene and biofilm formation. A study has shown that Bap plays a role in static biofilm maturation and maintenance, increasing biofilm thickness on glass surfaces ${ }^{(7)}$.

From data presented in this study, we concluded that, biofilm formation is influenced by Bap genes, the ability of $A$. baumannii to construct or form biofilms could cause a high level of antibiotic resistance and survival properties. A. baumannii isolates are capable to form biofilms might be selected under antibiotic pressure, or conversely, $A$. baumannii might acquire resistance to multiple drugs from the biofilm communities.

\section{Acknowledgments}

The authors express their deepest gratitude to all staff of Microbiology Department, College of Medicine, Al- Nahrain University and staff of Laboratory Department of Children Welfare Hospital and Al- Imamein Al-Kadhimein Medical city for their endless cooperation by equipment and experiences.

\section{Author Contribution}

Talib: Preparation, performing and doing the tests of the research. Dr. Abd Al-Rahman: Interpretation the results done under her supervision, Dr. Ali: help in collection of samples.

\section{Conflict of interest}

The authors have no conflict of interest.

\section{Funding}

Self-funding.

\section{References}

1. Munoz-Price LS, Weinstein RA. Acinetobacter infection. N Engl J Med. 2008; 358(2): 1271-81. doi: 10.1056/NEJMra070741.

2. Perez F, Hujer AM, Hujer KM, et al. Global challenge of multidrug-resistant Acinetobacter baumanni.
Antimicrob. Agents Chemother. 2007; 51: 3471-84. doi: 10.1128/AAC.01464-06.

3. Imane M, Hafida $H$, Samia B, et al. Biofilm formation by Acinetobacter baumannii isolated from medical devices at the intensive care unit of the University Hospital of Tlemcen (Algeria). African J Microbiol Res. 2014; 8(3): 270-6. doi: 10.5897/AJMR2013.6288.

4. Hassan A, Usman J, Kaleem F, et al. Evaluation of different detection methods of biofilm formation in the clinical isolates. Braz J Infect Dis. 2011; 15(4), 305-11. doi: https://doi.org/10.1016/S14138670(11)70197-0.

5. McConnell MJ, Actis L, Pachón J. Acinetobacter baumannii: Human infections, factors contributing to pathogenesis and animal models. FEMS Microbiol Rev. 2013; 37(2): 130-55. doi: 10.1111/j.15746976.2012.00344.x.

6. Babapour E, Haddadi A, Mirnejad R, et al. Biofilm formation in clinical isolates of nosocomial Acinetobacter baumannii and its relationship with multidrug resistance. Asian Pac J Trop Biomed. 2016; 6(6): 528-33.

doi:

https://doi.org/10.1016/j.apjtb.2016.04.006.

7. Loehfelm TW, Luke NR, Campagnari AA. Identification and characterization of an Acinetobacter baumannii biofilm-associated protein. J Bacteriol. 2008 Feb;190(3):1036-44. doi: 10.1128/JB.01416-07.

8. Gaddy JA, Tomaras AP, Actis LA. The Acinetobacter baumannii 19606 OmpA protein plays a role in biofilm formation on abiotic surfaces and in the interaction of this pathogen with eukaryotic cells. Infect Immun. 2009; 77(8): 3150-60. doi: 10.1128/IAI.00096-09.

9. Brossard KA, Campagnari $A A$. The Acinetobacter baumannii biofilm-associated protein plays a role in adherence to human epithelial cells. Infect Immun. 2012; 80(1): 228-33. doi: 10.1128/IAI.05913-11.

10. Badmasti F, Siadat SD, Bouzari S, et al. Molecular detection of genes related to biofilm formation in multidrug-resistant Acinetobacter baumannii isolated from clinical settings. J Med Microbiol. 2015; 64(Pt 5): 559-64. doi: 10.1099/jmm.0.000058.

11. Sambrook J, Russell DW. Molecular cloning: a laboratory manual Cold Spring Harbor. New York, USA, Cold Spring Harbor Laboratory Press; 2001.

12. Al-Kadhmy IMS, Ali ANM, Salman IMA, et al. Molecular characterization of Acinetobacter baumannii isolated from Iraqi hospital environment. New Microbes New Infect. 2017; 21: 51-7. doi: 10.1016/j.nmni.2017.10.010.

13. Ghajavand H, Esfahani BN, Havaei SA, et al. Molecular identification of Acinetobacter baumannii isolated from intensive care units and their antimicrobial resistance patterns. Adv Biomed Res. 2015; 4: 110. doi: 10.4103/2277-9175.157826.

14. Al Jarousha AM, El Jadba AH, Al Afifi AS, et al. Nosocomial multidrug-resistant Acinetobacter baumannii in the neonatal intensive care unit in Gaza City, Palestine. Int J Infect Dis. 2009; 13(5): 623-8. doi: 10.1016/j.ijid.2008.08.029. 
15. Babakir-Mina M, Rashid K, Beg SS, et al. "Epidemiological Characteristics and Antibiotic Resistance of Acinetobacter baumannii Isolated from Burn Patients. EC Microbiology. 2017; 7.4: 112-20.

16. Qureshi ZA, Hittle LE, O'Hara JA, et al. Colistinresistant acinetobacter baumannii: Beyond carbapenem resistance. Clin Infect Dis. 2015; 60(9): 1295-303. doi: 10.1093/cid/civ048.

17. Tunyapanit $W$, Pruekprasert $P$, Laoprasopwattana $K$, et al. Antimicrobial susceptibility of Acinetobacter baumannii isolated from hospital patients. ScienceAsia. 2014; 40: 28-34. doi: 10.2306/scienceasia1513-1874.2014.40.028.

18. Al-Mously N, Hakawi A, Author C. Acinetobacter baumannii bloodstream infections in a tertiary hospital: Antimicrobial resistance surveillance. Int J Infect Control. 2013; 9: 2-2. doi: 10.3396/ijic.v9i2.012.13.

19. Thummeepak $R$, Kongthai $P$, Leungtongkam $U$, et al. Distribution of virulence genes involved in, biofilm formation in multi-drug resistant acinetobacter Baumannii clinical isolates. Int Microbiol. 2016; 19(2): 121-9. doi: 10.2436/20.1501.01.270.

20. Jain R, Danziger LH. Multidrug-resistant Acinetobacter infections: An emerging challenge to clinicians. Ann Pharmacother. 2004; 38(9): 1449-59. doi: 10.1345/aph.1D592

21. Rodríguez-Martínez, J. M., Nordmann, P., Ronco, E. \& Poirel, L. Extended-spectrum cephalosporinase in Acinetobacter baumannii. Antimicrob Agents
Chemother. 2010; 54: 3484-8. doi: 10.1128/AAC.00050-10.

22. Azizi O, Shahcheraghi $F$, Salimizand $H$, et al. Molecular analysis and expression of bap gene in biofilm-forming multi-drug-resistant Acinetobacter baumannii. Rep Biochem Mol Biol. 2016; 5(1): 62-72.

23. Rodríguez-Baño J, Martí $S$, Soto $S$, et al. Biofilm formation in Acinetobacter baumannii: Associated features and clinical implications. Clin Microbiol Infect. 2008; 14(3):276-8. doi: 10.1111/j.14690691.2007.01916.x.

24. Longo F, Vuotto C, Donelli G.. Biofilm formation in Acinetobacter baumannii. New Microbiol. 2014; 37(2): 119-27.

25. Choi CH, Lee JS, Lee $\mathrm{YC}$, et al. Acinetobacter baumannii invades epithelial cells and outer membrane protein $A$ mediates interactions with epithelial cells. BMC Microbiol. 2008; 8: 216. doi: 10.1186/1471-2180-8-216.

26. Fallah A, Rezaee MA, Hasani A. Frequency of bap and сраA virulence genes in drug resistant clinical isolates of acinetobacter baumannii and their role in biofilm formation. Iran J Basic Med Sci. 2017; 20(8): 849-855. doi: 10.22038/IJBMS.2017.9105.

Correspondence to Sura S. Talib

E-mail: sura.saadtalib@yahoo.com

Received Sept. $2^{\text {nd }} 2018$

Accepted Nov. 18 2018 